\title{
O processo de identificação de uma professora pré-serviço de inglês com a profissão durante o estágio curricular supervisionado
}

\author{
The process of identification of a preservice \\ English teacher with the teaching activity \\ during her training practice
}

Luciane Kirchhof Ticks*

Universidade Federal de Santa Maria - UFSM/CAPES/LabLer ${ }^{1}$

\begin{abstract}
RESUMO: Este artigo discute o processo de identificação de uma professora préserviço de inglês com a profissão, durante a realização do estágio curricular obrigatório em uma escola pública, no decorrer de 2007. Os dados foram coletados por meio de sessōes de visionamento e escritura de diários reflexivos e os procedimentos de análise são basicamente de Análise Crítica do Discurso (FAIRCLOUGH, 2003). Os resultados indicam que o processo de identificação da professora pré-serviço com a profissão e com o contexto escolar, durante o estágio curricular, constitui-se pelos / nos papéis sociais que ela assume - ou tem permissão de assumir - no decorrer de sua docência.

PALAVRAS-CHAVE: identidade, formação pré-serviço, Análise Crítica do Discurso

ABSTRACT: This article discusses the process of identification of a preservice teacher of English with her profession, during her teacher training practice in a public school in 2007. The data was collected through reflective sessions and the production of reflective diaries and the procedures of analysis are basically of Critical Discourse Analysis (FAIRCLOUGH, 2003). The results indicate that the process of identification of the preservice teacher with her profession and with the school context, during her training practice, is constituted by the social roles she incorporates - or is allowed to incorporate - during her teaching practice.

KEYWORDS: identity, pre-service teaching, Critical Discourse Analysis
\end{abstract}

* letstalksm\#terra.com.br

${ }^{1}$ Esta pesquisa foi desenvolvida no Programa de Pós-Graduação da UFSM (PPGL), sob a orientação da Prof. Dra. Désirée Motta-Roth (UFSM/DLEM/LABLER). 


\section{Introdução}

Ao escolher a identidade como foco de investigação, a linguística aplicada se depara com a problemática de discutir algo que, na definição de Coracini (2007, p. 153), "é sempre uma ilusão, um sentimento ou uma sensação de totalidade que nutre o imaginário do sujeito e o tranqüiliza”. Em outras palavras, o processo de identificação, por meio do qual nos projetamos, é provisório e variável (HALL, 2005, p. 12).

Moita Lopes (2003, p. 15) argumenta que essa busca pelo entendimento de quem somos e como nos posicionamos em relação ao mundo é resultado das mudanças culturais, sociais, econômicas, políticas e tecnológicas desencadeadas pela sociedade e experienciadas em comunidades locais específicas. Há nas práticas cotidianas, que vivemos um questionamento constante dos modos de viver a vida social que tem afetado a compreensão da classe social, do gênero, da sexualidade, da idade, da raça, da nacionalidade etc., em resumo, de quem somos na vida social contemporânea. A identidade, portanto, constitui-se sociohistoricamente (HALL, 2005, p. 13).

Levando em consideração essa perspectiva de identidade como processo, este artigo procura investigar a identidade do professor de línguas, em particular de língua inglesa. Para tanto, analisamos o processo de identificação de uma professora pré-serviço com a profissão e os papéis que assume no contexto de sala de aula, durante a realização do estágio supervisionado, em uma escola pública da cidade de Santa Maria (RS), no decorrer de 2007. Os resultados ${ }^{2}$ deste estudo de caso apontam para o fato de que o processo de identificação do professor de inglês pré-serviço com a profissão depende diretamente dos papéis que pode (ou tem permissão de) assumir no contexto da escola pública. Mais especificamente, o processo depende do seu empoderamento como professora de língua inglesa pré-serviço naquele contexto.

\section{Pressupostos teóricos}

Se percebemos a construção identitária como um processo que se dá nas práticas, nas atividades realizadas diariamente (MOITA LOPES, 2003),

\footnotetext{
${ }^{2}$ Os dados apresentados neste artigo fazem parte de uma tese de doutorado, defendida em dezembro de 2008, que tinha por objetivo discutir e reconfigurar as concepções de aprendizagem, a prática pedagógica e as identidades de três professoras de inglês pré e em serviço.
} 
precisamos considerar que sua construção tem início, portanto, na infância, a partir das relaçõos que o indivíduo estabelece com os outros no contexto social no qual é criado. Para Berger e Luckmann (1985, p. 173), o espaço social no qual ele se desenvolve é dialético, está sempre em curso e é composto de três momentos: a exteriorização, a objetivação e a interiorização. Nele, o indivíduo exterioriza seu próprio ser no mundo social e interioriza este mundo como uma realidade objetiva.

No conceito de identidade social e individual proposto por Fairclough (2003, p. 223), reconhecemos as duas dimensões descritas por Berger e Luckmann. Parte do que Fairclough (2003, p. 223) chama de identidade social está intrinsecamente relacionada às circunstâncias sociais nas quais o indivíduo nasce e sofre a primeira socialização. A outra parte é adquirida mais tarde, quando o indivíduo assume papéis sociais, como a profissão de professor. Fairclough igualmente reconhece a relação dialética existente entre esses dois aspectos da identidade (2003, p. 223).

Segundo o autor (Idem, p. 160-61), precisamos ser capazes de assumir papéis sociais e personificá-los, caracterizando-os com traços da nossa própria personalidade (individual), se desejamos desenvolver a identidade social no seu sentido mais completo. Seguindo essa dialética, o desenvolvimento do indivíduo enquanto agente social está dialeticamente interconectado ao desenvolvimento da sua personalidade.

Assim, o foco na Identificação - como as pessoas se identificam e são identificadas por outros, através da análise textual - joga luz sobre essa dialética entre identidade pessoal e social: o modo de ser do indivíduo social, ou ainda, sua identidade no aspecto discursivo da linguagem, que Fairclough chama de "Estilos". O autor lembra que " $\mathrm{t}]$ he texturing of identity is thoroughly embedded in the texturing of social relations" 3 (Idem, p. 166). Nesse sentido, o modo como os indivíduos se comprometem com seus textos contribui para o processo de identificação de si mesmos, ou seja, para o processo de texturização identitária. O sujeito é evocado pela atividade da palavra (FOUCAULT, 2004, p. 68).

Por essa razão, levamos em consideração que as escolhas que o professor faz ao desenvolver sua prática pedagógica constituem sua identidade

\footnotetext{
${ }^{3}$ A texturização da identidade está cuidadosamente posicionada na texturização das relações sociais.
} 
profissional (COLDRON; SMITH, 1999, p. 713). Desse modo, a identidade é um construto social, constituída pelas práticas discursivas vivenciadas pelas participantes, e não como uma visão individual, como parte da natureza da pessoa (MOITA LOPES, 2003, p. 20).

\section{Metodologia}

Este artigo discute os papéis assumidos por uma professora pré-serviço $\left(\right.$ Cecília $\left.{ }^{4}\right)$, durante a realização do seu estágio curricular supervisionado, em uma escola pública de Santa Maria, em 2007. A coleta de dados aconteceu por meio de dois instrumentos de pesquisa: 1) sessões de visionamento acerca das ações em sala de aula; 2) diários reflexivos (QUADRO 3.1).

\section{QUADRO 3.1}

Procedimentos, perguntas norteadoras e fontes de coleta de dados

\begin{tabular}{|c|c|c|c|}
\hline $\begin{array}{l}\text { Período de } \\
\text { coleta do } \\
\text { corpus / } \\
\text { número de } \\
\text { encontros }\end{array}$ & Procedimentos & Perguntas norteadoras & $\begin{array}{c}\text { Fontes de } \\
\text { coleta de } \\
\text { dados }\end{array}$ \\
\hline $\begin{array}{l}\text { Maio-dez/ } \\
2007 \\
\\
29 \\
\text { Encontros }\end{array}$ & $\begin{array}{c}\text { Visionamento } \\
\text { (Reflexões acerca da } \\
\text { configuração de seus } \\
\text { papéis em sala de aula). }\end{array}$ & $\begin{array}{l}\text { - Como ocorreu a apresentação do } \\
\text { conteúdo? } \\
\text { - Como tu trabalhaste as respostas } \\
\text { dadas pelos alunos? } \\
\text { - Podes dar um exemplo disso que } \\
\text { comentaste? } \\
\text { - Qual foi o teu papel nessas } \\
\text { atividades? } \\
\text { - Que outra postura / papéis tu } \\
\text { adotarias na aula / atividade? Por quê?? }\end{array}$ & $\begin{array}{l}\text { Gravações } \\
\text { em áudio }\end{array}$ \\
\hline $\begin{array}{l}\text { Encontros } \\
\text { semanais: } \\
\text { 2h30min/ } \\
\text { encontro }\end{array}$ & $\begin{array}{l}\text { Escritura de diários } \\
\text { (Reflexões acerca da } \\
\text { configuração de seus } \\
\text { papéis em sala de aula) }\end{array}$ & $\begin{array}{l}\text { - Como tu avalıas o teu } \\
\text { desempenho e o teu papel no } \\
\text { processo de condução da aula? } \\
\text { - O que te levou a fazer essas } \\
\text { escolhas, seguir esse caminho? } \\
\text { - Tu farias alguma mudança na tua } \\
\text { atuação em sala de aula? }\end{array}$ & $\begin{array}{c}\text { Diários } \\
\text { reflexivos }\end{array}$ \\
\hline
\end{tabular}

${ }^{4}$ Nome fictício. 
A seguir, discutimos os critérios de análise utilizados nesta investigação.

\section{Critérios de análise}

Procuramos evidenciar o processo de (re)configuração identitária de Cecília, durante sua prática pedagógica na escola pública. Para tanto, adotamos dois critérios: a identificação de temáticas e a identificação dos papéis de professora. Esses critérios serão descritos a seguir.

1) Identificação de temáticas: na análise preliminar do corpus, percebemos que a participante, ao discutir suas percepçôes acerca de seus papéis no contexto de sala de aula, norteia suas reflexôes por uma temática central. Essa temática (QUADRO 3.2) encadeia os sentidos que deseja dar às suas reflexões acerca dos papéis que assume como professora naquele contexto.

QUADRO 3.2

Temática identificada no discurso de Cecília.

\begin{tabular}{c|c}
\hline Participante & Cecilia \\
\hline Temática & Relaçōes sociais na escola pública \\
\hline
\end{tabular}

No discurso de Cecília, a temática recorrente são as relações sociais estabelecidas na escola pública e, em particular, sua relação com os alunos no contexto da sala de aula.

2) Identificação dos papéis de professora: após a identificação das temáticas, procuramos analisar a natureza dos papéis de professora, que assume no contexto de sala de aula. Os papéis (categorias de análise) que emergiram de seu texto estão em destaque no QUADRO 3.3, bem como as respectivas evidências textuais retiradas do corpus. Os procedimentos de análise adotados são basicamente de Análise Critica do Discurso (FAIRCLOUGH, 2003). 
QUADRO 3.3

Papéis de professora assumidos pela participante (categorias de análise)

\begin{tabular}{c|l}
\hline \multicolumn{2}{c}{ Cecília } \\
\hline $\begin{array}{c}\text { Papel de professora } \\
\text { Autoritária e } \\
\text { disciplinadora }\end{array}$ & $\begin{array}{l}\text { Excerto do corpus } \\
\text { aterrorizar um pouco. [...] eu me pergunto se eu realmente } \\
\text { deveria tomar uma atitude de disciplina de uma maneira mais } \\
\text { explíc, mais rígida, botar alguém pra fora [...] Eu pensei [...] }\end{array}$ \\
\hline $\begin{array}{c}\text { em chegar um dia sem avisar [e] dar uma prova. } \\
\text { Conciliadora }\end{array}$ & $\begin{array}{l}\text { Dá voz a si mesma e ao aluno } \\
\text { Eles mesmos reconhecem isso e parece que a ideia seria mesmo } \\
\text { tirar da sala. A ideia dos próprios colegas [...] se a professora } \\
\text { tirasse da sala seria melhor. }\end{array}$ \\
\hline $\begin{array}{c}\text { Engajada, política } \\
\text { e pedagogicamente, } \\
\text { com o contexto }\end{array}$ & $\begin{array}{l}\text { [...] em cada nova circunstância, eu sou chamada a me } \\
\text { posicionar e esse posicionamento eu pretendo que seja crítico, } \\
\text { que seja consciente, engajado, talvez, não seja neutro. Mas isso } \\
\text { não é uma [...] decisão pessoal, é um exercício. }\end{array}$ \\
\hline
\end{tabular}

A participante foi identificada pelo nome, o número do excerto e a data da sessão / diário reflexivo:

Cecília 1\#14.05 - Cecília, excerto 1, coletado em 14 de maio de 2008.

A seguir, discutimos os resultados obtidos nesta investigação.

\section{Discussão dos resultados - Cecília: "quero ser professora, mas não na escola pública"}

Cecília precisou administrar, durante o trabalho na escola pública (doravante EPF), em 2007, inúmeros conflitos indisciplinares vivenciados com a turma de 25 alunos de $7^{\text {a }}$ Série. Esses conflitos povoam todas as suas reflexões ao longo desta pesquisa e são, portanto, centrais também na construção de sua identidade como professora de inglês. Desse modo, procuramos tecer um relato de como as tentativas de problematização desses conflitos delinearam sua identidade como professora de inglês, sua identificação com a profissão, com o contexto escolar, e os papéis assumidos nesse processo. 
Os alunos que integram essa turma recebem, na EPF, grande atenção por parte dos professores, coordenação e vice-direção. Nos conselhos de classe, os professores são unânimes ao afirmar já terem feito "de tudo" para "resolver" as questôes indisciplinares: chamar a atenção na sala de aula, tirar da sala, enviar para a vice-direção, comunicar aos pais para um entendimento com a família. Segundo os relatos de Cecília, os professores, de um modo geral, entendem que todo o problema se concentra nos alunos. São eles os responsáveis pelos conflitos, pois não cedem à autoridade dos professores e da escola. Cecília faz uma leitura diferente do grupo desde o princípio. Por essa razão, procura desenvolver estratégias alternativas àquelas tradicionalmente propostas pelos demais professores e pela instituição.

Cecília constrói sua identidade como professora no seu posicionamento dentro da narrativa e em relação às personagens que nela interagem (ROLLEMBERG, 2003, p. 260). Desse modo, ao problematizar a situação, avalia que não deseja um "silêncio sepulcral", mas uma atenção inicial dos alunos para poder explicar a atividade. Percebe, então, que a liberdade também é um processo, que precisa ser ensinado, e que os alunos estão acostumados a um ambiente hierarquicamente organizado, que ela define como sentar em fila, quietos, para copiar as atividades do quadro (1\#14.05). Não se identifica, portanto, com uma relação alunos-professora fortemente hierarquizada e parece buscar um equilíbrio entre a autoridade do professor e o desenvolvimento da liberdade dos alunos (FREIRE, 2003b, p. 82).

\section{Cecília 1\#14.05:}

Mas não é a questão de ter aquele silêncio sepulcral [...] a conversa é legal, a gente estimula isso desde que seja produtivo [...] eles são tão acostumados a ter aquele tipo de aula: quieto, olha pro quadro e copia, que quando eles se deparam com uma pequena possibilidade de liberdade, não sabem o que fazer $[\ldots]$

Cecília (2\#14.05) elabora, assim, as primeiras estratégias para marcar sua autoridade. Todavia, sua primeira iniciativa, ao tentar posicionar sua identidade como professora, é resgatar estereótipos profissionais que provavelmente povoaram suas experiências como aluna ("aterrorizar um pouco", "botar pra fora... dar prova sem avisar"). Tais estratégias demonstram ainda uma tentativa de identificação com o perfil da professora Dóris, a quem observa há um ano na escola. Porém, não parece estar muito convencida de sua eficácia e acaba por deixá-las de lado. 


\section{Cecília 2\#14.05:}

É, de repente aterrorizar um pouco. [...] eu me dou muito bem com eles, [...] mas eles não tem respeito pela figura do professor que exige a disciplina como eles têm com a Dóris [...] então eu me pergunto se eu realmente deveria tomar uma atitude de disciplina de uma maneira mais explícita, mais rígida, botar alguém pra fora [...] Eu pensei [...] em chegar um dia sem avisar dar uma prova [...] Eu dou a prova, e daí? recolho e vou embora? [...]

Em junho, os conflitos com a turma (conversa paralela, dispersão dos alunos e recusa em fazer as atividades) ficam insustentáveis para Cecília, que, em meio à aula, resolve fazer "um mini-escândalo": bate palmas até retomar a atenção dos alunos. Cecília tem dificuldade de criar uma rotina de trabalho que lhe garanta, no início da aula, alguns minutos de atenção dos alunos para explicar a atividade do dia (3\#18.06).

\section{Cecília 3\#18.06:}

[...] Foi bem bom [...] Porque eu frisei: isso é o que eu quero: um tempo pra explicar, depois eles têm como conversar, têm como interagir, não precisam ficar quietos a aula toda, né?

Embora a estratégia tenha dado certo, Cecília se sente agredida pela própria atitude tomada e questiona o porquê de o professor precisar lançar mão de atitudes dessa natureza para conseguir trabalhar na escola.

Cecília 4\#18.06:

[...] Eu acho extremamente agressivo, violento se posicionar assim. Eu fiz isso a muito contra gosto [...] eu não me sinto à vontade, absolutamente, em fazer o que eu fiz hoje e se eu tivesse que ser professora nessas condiçôes eu seria extremamente infeliz [...] $\mathrm{O}$ professor não deveria ser obrigado a impor a sua presença assim, por meio do berro, do grito. O que teria que se fazer pra que isso não fosse necessário? [...]

Cecília vive o conflito discutido por Freire (2003a) de que o professor, assim como a sociedade brasileira, engatinha no processo de aprender a se movimentar por meio de relações democráticas. Para Freire, é preciso evitar os extremos: de um lado o autoritarismo e, do outro, a licenciosidade.

Nem o professor que, inseguro, não consegue afirmar sua autoridade nem tampouco o que, arrogante, a exacerba, mas o professor que, jamais negando-se enquanto autoridade, jamais nega, tampouco, a liberdade dos educandos (FREIRE, 2003a, p. 202). 
Ela procura encontrar esse ponto de equilíbrio e decide tirar da sala aqueles alunos e alunas que atrapalham a aula, para conversar individualmente, possibilidade aventada pela própria turma $(5 \# 18.06)$.

\section{Cecília 5\#18.06:}

[...] os próprios colegas identificam os alunos que transtornam a aula. Eles mesmos reconhecem isso e parece que a ideia seria mesmo tirar da sala. A ideia dos próprios colegas [...] se a professora tirasse da sala seria melhor $[\ldots]$ uma cultura de diálogo, que eles pudessem falar.

Acredita que deve desenvolver uma estratégia que seja coerente com suas crenças, já que não se sente à vontade e considera violento gritar para obter silêncio. Percebe também a necessidade de justificar, para os alunos, toda e qualquer atitude tomada (6\#20.08).

\section{Cecília 6\#20.08:}

[...] eu não sei ser assim tão sanguínea, né? [...] Então, eu sinto essa necessidade $[\ldots]$ de justificar. Eu tô fazendo assim porque vocês têm a opção de se movimentar com liberdade na sala de aula. Então eu acho que eu tenho que desenvolver uma maneira de me impor dentro daquilo que eu sou.

Em setembro, vivencia uma nova crise e, desta vez, pensa em "juntar suas coisas e desistir" (7\#10.09). Todavia, acredita que essa teria sido uma atitude "covarde" e volta atrás.

\section{Cecília 7\#10.09:}

[...] aquilo me deu uma angústia, um terror, e eu fui pra minha mesa pra juntar as minhas coisas e ir embora naquele momento, foi um ímpeto de sair dali. E aí eu me acalmei, pensei que seria feio e covarde sair correndo, mas essa era minha intenção, e aí, na terceira vez, eu consegui.

Ao refletir acerca de uma nova estratégia de atuação, Cecília decide preparar uma dinâmica de grupo na qual os problemas vivenciados por ela com a turma pudessem ser discutidos (8\#17.09). Nessa dinâmica, os alunos fizeram uma lista de suas reclamações em relação aos professores e à escola e uma outra lista de reclamaçôes que os professores normalmente fazem a seu respeito. Depois disso, assistiram ao vídeo da aula de inglês no sentido de tentar identificar quais das reclamações listadas podiam ser observadas no comportamento da professora e dos alunos na aula de inglês. Cecília desejava 
que percebessem como o papel deles é fundamental para a realização de um trabalho em grupo. Tenta, portanto, construir sua identidade como professora, sempre por meio da conciliação com o grupo.

\section{Cecília 8\#17.09:}

[...] Os alunos assistiram ao vídeo da nossa aula anterior, em que fica nítida a minha grande dificuldade de obter atenção e silêncio para explicar a atividade proposta naquele dia [...] Com isso nossa intenção foi demonstrar o quanto o trabalho em grupo depende do comprometimento de todos.

A dinâmica funcionou como uma catarse para os alunos, que aproveitaram a oportunidade para falar sobre o "desprazer" gerado pelo contexto escolar. A partir desse ponto, Cecília começa a desviar o problema de si mesma e dos alunos para o contexto escolar. Levanta a hipótese, que será confirmada no conselho de classe, de que a escola não está interessada em ouvir o que os alunos têm a dizer, disseminando uma cultura não dialógica e de descrença - no aluno - em relação a tudo que é proposto pela escola (9\#17.09).

\section{Cecília 9\#17.09:}

[...] a escola não tá "a fim" de ouvir reclamação a respeito de professor [...] Parece realmente que o problema da dispersão é de âmbito mais geral, refletindo o total desinteresse do aluno pela escola como um todo [...]

A dinâmica de grupo também serviu para que fossem definidas estratégias a serem utilizadas por Cecília (10\#17.09) em situações de indisciplina, estratégias estas discutidas em parceria com os alunos.

\section{Cecília 10\#17.09:}

[...] Então eles falaram duas coisas que eu já fiz, sabe? Tirar pra fora e conversar [individualmente], eu vou ver se eu faço isso mais seguido agora [....] e tirar nota, descontar. E isso é uma estratégia que eles concordam. Me parece justo.

No conselho de classe, em setembro, Cecília, inicialmente ignorada pela orientadora educacional, questiona os demais professores acerca de como lidavam com a indisciplina em sala de aula. Embora os professores coloquem os alunos para fora da sala, a atitude não é "aprovada" pela orientadora, pois eles ficam apenas "transitando" de uma instância a outra da escola. Cecília percebe, então, que os esforços feitos pela escola não solucionam o problema, apenas o transferem de um lugar para o outro, de um dia para o outro. Segundo 
Cecília, a orientadora informou que os professores "devem" resolver o problema "em sala de sala" e não o empurrar para frente, como regularmente têm feito. A participação de Cecília (11 e 12\#17.09) no conselho deixa nela a percepção de que o professor estagiário de inglês - porque a de ciências foi convidada a falar - pouco ou nenhum valor tem para a escola, embora esta se aproprie de seu trabalho.

Cecília 11\#17.09:

[...] ela [a orientadora educacional] chamou todos os professores, inclusive chamou uma estagiária do curso de ciências que tava ali [...] E aí ela ia mudar de assunto e ela não ia me chamar e eu ergui a mão e disse "eu quero falar", né? E ela sabia que eu tava ali, que eu era estagiária de inglês. Mas eu fui sumariamente ignorada. [...] E daí ela [a orientadora educacional] falou que não é legal fazer isso porque eles ficam transitando de supervisão pra coordenação pedagógica e, assim, dentro da escola, como se não existisse alguém responsável ou capacitado o suficiente pra tratar disso, então eles ficam sendo jogados.

\section{Cecília 12\#17.09:}

Então eu me senti bem lixo [...], me senti desconsiderada, descartada no conselho.

Para corroborar a hipótese de que a escola não está preparada para promover uma discussão em torno da questão disciplinar, Cecília relata a dinâmica de grupo desenvolvida pela orientadora educacional, logo após o conselho de classe. A orientadora trouxe uma citação de Einstein para desencadear a reflexão (13\#17.09). Cecília entende que a ideia é revolucionária, pois a educação, nos termos definidos pelo cientista alemão, aparelha o aprendiz para se movimentar criticamente no mundo (14\#17.09).

\section{Cecília 13\#17.09:}

[A citação] dizia que os alunos deveriam ser ensinados a conhecer e compreender os valores dessa sociedade e eles deveriam receber também uma educação para o que fosse moralmente bom e para o belo. Então o estudo teria essas duas dimensões: a educação ética, a educação estética e, além disso, a compreensão e o reconhecimento dos valores que estruturam aquela sociedade $[. .$.

Cecília 14\#17.09:

[...] Nossa, como isso pode ser subversivo e revolucionário, num sentido em que uma pessoa seja aparelhada dessa maneira, né, pra se movimentar no mundo. 
Entretanto, surpreende-se (15\#17.09) e decepciona-se com a forma como o trabalho foi encaminhado, pois a orientadora utilizou a citação para listar uma série de obrigações (do aluno) que já foram naturalizadas pelo discurso da instituiçãao escolar. Por essa razão, são repetidas, mas não legitimadas pelos alunos (16\#17.09). Foucault (apud GREGOLIN, 2006, p. 132) lembra que cada sociedade, nesse caso a escola, tem seu próprio regime de verdade e, nesse sentido, empodera aqueles que têm "o encargo de dizer o que funciona como verdadeiro" dentro dos limites sociais nos quais atua. Nesse sentido, Coracini (2007, p. 105) argumenta que, quando a um grupo são concedidos apenas "deveres", não podemos esperar dele que respeite a ordem, pois o modo que encontra para se fazer ouvir é pela criação de outras "regras", outras "leis".

\section{Cecília 15\#17.09:}

[...] fiquei extremamente decepcionada com a maneira como ela trabalhou isso na aula [...] Ah, porque nós temos que respeitar os mais velhos, aceitar os valores que nos são passados [...] E que também a gente tem que [...] aprender a se comportar de acordo com o que seja moralmente bom $[\ldots]$

\section{Cecília 16\#17.09:}

[...] eles tão sendo doutrinados nesse discurso Eles falam exatamente o que eles sabem que a pessoa tá esperando ouvir, né? Então é aquele discurso manjado [...] mas é um discurso vazio pra eles [...] E eles são espertos o suficiente pra saber se movimentar no meio desse discurso, que não significa nada.

Cecília, então, desconstrói o discurso da orientadora argumentando que, em nenhum momento, esta procurou problematizar o que seria o "moralmente bom" e tampouco discutiu o fato de a citação não implicar a aceitação passiva de valores pela sociedade (17\#17.09). Percebe que, embora a professora estivesse "bem intencionada", seu despreparo provoca não um diálogo com os alunos, mas estimula uma atitude de "passividade" neles: devemos aceitar os valores, porque são tradicionais, sem questionamento (18\#17.09). Nesse momento, Cecília se dá conta de que os valores não são escolhas individuais, mas construídos sociohistoricamente dentro de uma cultura e, se não desnaturalizados, são transformados em verdades inquestionáveis (FAIRCLOUGH, 1989, 1992). 


\section{Cecília 17\#17.09:}

O que é moralmente bom, sabe? Então tu vai lá e cata o moralmente bom, despreza o moralmente ruim. É só uma questão de fazer uma escolha, né? [...] Como poderia ser questionada essa absorção passiva dos valores, [...] reconhecer, perceber, eram esses os termos, quer dizer, detectar pra poder se movimentar em relação a isso, mas não significa aceitar. Muito pelo contrário, pode significar negar e construir valores novos enquanto sociedade. [...]

\section{Cecília 18\#17.09:}

Então eu fico pensando, assim, quanta boa vontade da pessoa, ela tinha boa vontade, mas aquilo se perde na falta de preparo pra lidar. E aí vai sedimentando $[\ldots]$ a passividade. Então se aceita, se valoriza, porque é uma "tradição".

Moita Lopes (2003, p. 21) pondera que as instituições legitimam, institucional, cultural e historicamente, certas identidades sociais, ao mesmo tempo em que encarceram e patologisam outras, considerado-as ilegítimas. No grupo de Cecília, a indisciplina é tratada como uma patologia, um desvio do comportamento padrão e, em nenhum momento, como uma possível reação provocada por um sentimento de insatisfação por parte daqueles que a exercem. Coracini (2003, p. 151) critica a escola no momento em que sua política abafa as diferentes vozes que constituem os sujeitos que nela atuam, transformandoos em "repetidores" de outras vozes: do livro didático, do professor, da orientadora. Nesse sentido, legitima "esquemas e modelos fornecidos a priori" do bom aluno, bom leitor (Ibidem) e reforça o medo de lidar com o diferente, o estranho, silenciando o aluno pela relação castradora do poder (Ibid., p. 157).

A experiência da dinâmica observada por Cecília faz com que repense as prioridades da sua proposta de trabalho e, consequentemente, seu papel como professora. Ela (19\#17.09) se angustiava especialmente por não estar conseguindo desenvolver as atividades dentro do cronograma planejado, tendo em vista o comportamento dispersivo dos alunos. Em uma de nossas reflexões, discutimos que o processo de ensinar com foco no desenvolvimento da cidadania não só implica ministrar o conteúdo planejado em um dado cronograma, mas refere-se também ao desenvolvimento de rotinas de trabalho com os alunos, a administração de conflitos e o estreitamento de relações sociais. A discussão conforta Cecília (20\#17.09), que procura transferir suas atenções e prioridades como professora e do cronograma fixado no início dos trabalhos para o próprio processo de aprendizagem dos alunos. 
Cecília 19\#17.09:

Acho que ainda não se configurou um sistema de sala de aula que funcione assim, mas [...] se eu não conseguir fazer tudo que a gente planejou, isso não vai ser tão importante se eu conseguir fazer outras coisas, se eu conseguir despertar alguma coisa que talvez não vá surtir efeito agora, vai surtir efeito um dia [...] Foi muito bom isso que tu me falou.

\section{Cecília 20\#17.09:}

A cartilha, todo esse projeto em torno do mercado, da compra e venda, a gente vai fechar. Vai fechar quando a gente achar que tem que fechar. E isso é uma vitória. Agora, fecha-se o ciclo. Deu, terminou! [...] Mas essa sensação é muito boa, que eu fiz até o ponto que eu achei que tinha que ser feito.

Em outubro, ao trabalhar com a temática do meio ambiente, Cecília escolhe, como estratégia "de sedução" para obter atenção dos alunos e envolvimento deles nas atividades, tirá-los do "contexto viciado" da sala de aula. Eles saíram da escola no papel de observadores para capturar, ao seu redor, impressóes específicas acerca de diferentes aspectos relativos ao meio ambiente. A primeira expectativa de Cecília era a de que eles virtualmente "enlouqueceriam" ao passarem pelos portôes da escola (21\#22.10). Todavia, para sua surpresa, isso não aconteceu. A nova experiência enche Cecília de esperança de que talvez tenha encontrado uma alternativa para administrar os conflitos disciplinares no grupo (22\#22.10).

Cecília 21\#22.10:

[...] eles se sentem à vontade simplesmente pelo fato de tu sair daquele ambiente da sala de aula viciado. Tu consegue fazer com que eles relaxem, porque eu acho que todo mundo participou, né? [...] Eu gostei demais e eu me senti muito bem.

Cecília 22\#22.10:

Eu fiquei pensando que a partir de agora a gente tem que tentar bolar esse tipo de estratégia pra tornar a coisa um pouco mais fluída, um pouco mais tranquila $[\ldots]$

A oportunidade de sair da sala de aula também é aproveitada por Cecília (23\#22.10) no sentido de tentar redimensionar os problemas de relacionamento entre os próprios alunos da turma. Por meio de um sorteio, Cecília consegue fazer com que duas alunas, que apresentam animosidade, trabalhem juntas na 
atividade de observação. Ela acredita que o sucesso da experiência mostra aos alunos que, embora muitas vezes discordando, podem trabalhar juntos colaborativamente, habilidade interpessoal fundamental para a construção de uma sociedade cidadã. Freire (2003a, p. 213) argumenta que a razão de ser da educação libertadora está no seu impulso conciliador. Nesse caso, a conciliação é promovida pelo próprio trabalho colaborativo.

Cecília 23\#22.10:

Essa ideia de que a gente muitas vezes vai trabalhar com pessoas que a gente não se dá ou que se pudesse escolher não trabalharia [...] e a turma toda vê que elas conseguiram [...] Então, isso é uma mensagem que transita naquele contexto ali, que pessoas diferentes podem trabalhar junto, como elas.

A vivência de administrar sua relação com os alunos, bem como os conteúdos a serem trabalhados em sala de aula, alimentam em Cecília a consciência de que o professor precisa se preparar antecipadamente para lidar com a complexidade desse contexto (24\#05.11). Exemplo disso é a atitude assumida pelos alunos de que, por estarem fisicamente presentes às aulas, seu futuro estará garantido, não havendo necessidade de grandes esforços e participação. Cecília percebe a necessidade de desnaturalizar tais crenças, principalmente porque, para ela, esses falsos mitos despreparam os indivíduos para lidar com o inesperado (25\#05.11).

Cecília 24\#05.11:

Como o professor tem que estar bem informado pra poder se movimentar nessa avalanche de informaçôes que eles trazem [...] no sentido de reforçar, despertar coisas que eles não pensaram ou mesmo desconstruir ideias que não se sustentam [...] e como não é fácil [...] chegar lá com o senso comum não, não rola [...]

Cecília 25\#05.11:

Eu estou na escola, então eu vou estudar e vou conseguir alguma coisa melhor do que o cara que está catando papel. Quem garante? Então essa ingenuidade também de achar [...], mesmo tu tendo consciência das oportunidades e do que tu tem que fazer, ainda pode dar tudo tão errado. Eu acho que a gente devia ser mais preparado também pra saber lidar quando as coisas dão errado.

Em novembro, ela repete a estratégia de trabalhar com os alunos ao ar livre, mas precisa, a todo o momento, fazê-los se responsabilizarem por suas 
escolhas (26\#12.11). Essa vivência ensina à Cecília que a colocação de regras para o bom andamento da aula não compromete a relação afetiva com os alunos, temor nutrido por ela até então (Cecília 27\#12.11), e tampouco impede o desenvolvimento de uma proposta pedagógica que seja libertária (FREIRE, 2003b, p. 82).

\section{Cecília 26\#12.11:}

[...] Daí, eu disse: vocês escolheram vir pra cá [...] se vocês em dois minutos não se organizarem a gente vai voltar pra sala de aula e nunca mais vem pra cá $[. .$.$] aí, se organizaram rapidinho.$

\section{Cecília 27\#12.11:}

[...] que quando uma pessoa chama [a atenção]: "olha, tu tá fazendo errado". Aquilo não é ofensivo pra ela [...] eu acho, eu acho [que] ela tá pedindo por limites, porque senão ela poderia se chocar. $\underline{E}$ isso não compromete o vínculo afetivo, né, que é uma coisa que eu sempre temia [...]

Ainda em novembro, a última estratégia utilizada por Cecília foi a de encaminhar os alunos indisciplinados à vice-direção da escola, com o apoio da professora regente. Embora ela tenha se esquivado de adotá-la durante todo o ano, Cecília se diz com a "consciência tranquila" por tê-la tomado, pois já havia tentado tudo que estivesse "ao seu alcance" (28\#19.11). Além disso, queria testar a hipótese de que, ao tirar o grupo de alunos mais dispersivos, a aula fluiria, hipótese confirmada por ela.

\section{Cecília 28\#19.11:}

[...] eu estava com a consciência tranqüila [...] eu já tinha tentado tudo que era possível em termos de civilidade pra lidar com eles: conversa, dinâmica de grupos, tirar pra fora pra conversar [individualmente].

A percepção que Cecília tem do grupo enviado para a vice-direção é a de que já desistiram da escola, embora ainda a freqüentem "fisicamente" (29\#19.11), crença também observada por Alonso e Fogaça (2007, p. 31). Esses alunos não se submetem aos padrōes comportamentais requeridos pela instituição, assumindo uma conduta de "anomia" (MERTON, 1968, p. 207), que, em outras palavras, significa a ausência de normas. Segundo Merton (1968, p. 192), "[...] pode representar o começo de um novo molde alternativo, com suas próprias pretensões distintas de validade moral". Segundo a classificação proposta por Merton (Ibid., p. 229), o grupo de Cecília pode ser reconhecido na conduta anômica de "rebelião", que pressupóe o afastamento 
dos objetivos dominantes de uma dada instituição social, no caso a escola, e de seus padrões vigentes, considerados arbitrários.

\section{Cecília 29\#19.11:}

[...] aquilo ali saturou tanto que eu acho que eles não acreditam que nada de bom possa surgir naquele contexto, sabe, eu acho que há uma desesperança assim, sei lá, eu acredito que não seja muito consciente.

Na primeira avaliação que Cecília (30\#26.11) faz do próprio processo de estágio, deixa clara sua insatisfação por não ter conseguido "seduzir" os alunos que apresentavam problemas disciplinares e não consegue avaliar a experiência apenas considerando o progresso dos demais.

Cecília 30\#26.11:

Apesar de eu conseguir reconhecer que vários alunos fizeram um baita progresso [...], então, foi muito gratificante [...] Só que o fato de eu ter sofrido tanto por causa do resto me pesa muito mais, de modo que eu não consigo avaliar o meu estágio positivamente [...] Eu não consigo ter esse distanciamento [...]

Cecília fez o estágio por uma obrigação curricular (31\#17.12). Não tinha qualquer pretensão de ser professora. Inicialmente, sua percepção acerca da profissão é a mesma que atribui aos alunos indisciplinados em relação à escola (29\#19.11). A "desconfiança” dela, no início do processo, em relação à profissão ("nada de bom poderia me acrescentar aquilo") é a dos alunos, mesmo que inconscientemente, acerca da escola (SOUZA, 2003, p. 342).

\section{Cecília 31\#17.12:}

E eu fui fazer estágio porque eu tinha a obrigação de fazer, eu não queria nada com aquilo, não achei que nada de bom poderia me acrescentar aquilo.

Cecília modifica sua percepção em relação à profissão ao longo do ano, por meio das oportunidades de reflexão que o trabalho desenvolvido durante o estágio proporcionou-lhe (32\#03.12). Embora deixe bastante explícito o quanto o estágio foi uma experiência dolorosa, reconhece que também isso ajudou a construir uma nova faceta identitária: a de professora (33\#03.12). Atribui a mudança ao "prazer" que sentiu ao desenvolver as atividades que estimularam o desenvolvimento de uma postura crítica no aluno, demonstrando a consciência do papel político que assume ao realizar a tarefa (39\#03.12). 


\section{Cecília 32\#03.12:}

[...] Apesar de toda a dor, de toda angústia que [...] o estágio [...], eu descobri $[\ldots]$ que eu quero ser professora e que eu vou ser professora [...]

\section{Cecília 33\#17.12:}

Quer dizer em cada situação, em cada nova circunstância, eu sou chamada a me posicionar e esse posicionamento eu pretendo que seja crítico, que seja consciente, né, engajado, talvez, não seja neutro. Mas isso não é uma [...] decisão pessoal, é um exercício. [...]

Todavia, sua identificação com a profissão não significa que deseje ou planeje trabalhar no Ensino Fundamental e Médio; ao contrário, a experiência garantiu a ela a certeza de que é capaz de fazê-lo, mas só o fará por necessidade econômica (34\#17.12). Para ela, portanto, ser professora na escola pública não é uma escolha, mas uma imposição financeira. Brun (2004, p. 90) argumenta que a atitude do professor em relação ao contexto escolar depende de suas "posiçōes filosóficas", estejam elas explícitas ou implícitas. Nesse sentido, tal a linhamento o leva a fazer escolhas, durante o processo de socialização na escola, que poderão fazê-lo recusar ou aceitar aquele contexto para a realização de sua prática profissional (COLDRON; SMITH, 1999, p. 715). Em outras palavras, a construção da identidade social, em geral, envolve a tomada de posicionamentos no espaço social (Ibid., p. 714).

Cecília 34\#17.12:

[...] eu não quero ser professora naquele contexto de ensino fundamental e médio. Eu pretendo ser professora de universidade, mas eu tenho uma segurança comigo, que é uma sensação de vitória sabe [...] se eu tivesse por uma necessidade econômica de dar aula numa escola de Ensino Fundamental e Médio [...], eu vi que eu sou capaz [...]

Cecília assume a mesma conduta anômica de "rebelião" (percebida entre seus alunos -29\#19.11) em relação à escola: não se identifica com os valores, as normas e as condutas adotadas pela instituição, criticando principalmente o modo como as relaçôes sociais entre orientação escolar / alunos, orientação escolar / estagiários, orientação escolar / professores nela estão configuradas. Portanto, não consegue projetar-se como professora naquele contexto profissional. Tsui (2007, p. 675) destaca duas "fontes" de formação identitária profissional: a) o indivíduo / profissional reconhece que possui a competência que sua comunidade de trabalho valoriza; b) essa comunidade oferece-lhe legitimidade de acesso à prática pedagógica. No caso de Cecília, embora 
reconheça que possui competência para ensinar naquele contexto específico, a comunidade de trabalho não lhe confere legitimidade profissional.

Para ela, a escola não pode ser incoerente a ponto de distanciar-se ou negar a própria dinâmica da vida: somos indivíduos em constante processo de aprendizagem. Entende que tal postura é resultado de um processo e que os professores não podem estimulá-la entre os alunos quando não a vivenciam (35\#03.12). Percebe, assim, que o indivíduo não é resultado de uma ação mecânica, de uma escolha pessoal, mas de um processo sociohistórico profundo e complexo (FREIRE, 2003a, p.224). O entendimento desse processo se dá por meio da educação. Nesse sentido, o pensamento e o saber das novas geraçōes se formam a partir da apropriação dos resultados da atividade cognitiva das gerações anteriores (LEONTIEV, 1983, p. 215).

\section{Cecília 35\#03.12:}

Isso é algo que se perdeu entre o professorado, né, então, se na vida [...] se na vida tudo é dinâmico, tudo é impreciso, tudo te exige o tempo todo a tomada de posição [...], por que na escola seria diferente? Por que o trabalho do professor seria diferente? E eu falo isso no sentido de que as pessoas, me parecem que pensam ainda que se formaram, estão prontas. $\mathrm{O}$ conhecimento [...] eu possuo, agora estou apta a por em prática. E isso é tão desconectado da própria dinâmica da vida [...]

Embora Cecília comece a pensar em si mesma como professora, essa identificação não se estende ao contexto conflituoso e extenuante da escola pública, uma vez que discorda dos valores que a ela subjazem. Além disso, o fato de ela não ter voz nas decisões referentes à administração dos conflitos vivenciados em sala de aula, frente à instituição escolar, impedem sua identificação com aquele contexto (TSUI, 2007, p. 678).

A experiência de Cecília durante o estágio permitiu que estivesse constantemente refletindo e reconstruindo sua prática pedagógica no sentido de procurar resolver os problemas vivenciados por ela e pela turma. Para Freire (2003a, p. 225), o envolvimento em situações de conflito "partejam" o processo de conscientização. Esse processo contribuiu para que construísse suas próprias representações do que seja ensinar e aprender com foco em uma perspectiva crítica da linguagem (FAIRCLOUGH, 1989; FREIRE, 2001a), bem como seu papel como professora. No início do processo, ventila a possibilidade de assumir o papel de professora autoritária (Categoria 1, QUADRO 4.1), reproduzindo identidades que, muito provavelmente, 
povoam sua memória, advindas de sua vivência escolar como aprendiz. Todavia, esse papel é logo questionado e abandonado por ela. Aos poucos, estabelece uma relação dialógica com os alunos, procurando negociar espaços e responsabilidades no contexto da sala de aula: papel de conciliadora (Categoria 2, QUADRO 4.1).

$$
\text { QUADRO } 4.1
$$

As escolhas léxico-gramaticais de Cecília e as representaçôes construídas na configuração de sua identidade como professora na escola EPF

\begin{tabular}{|c|c|c|}
\hline $\begin{array}{l}\mathrm{N}^{\circ} \text { do } \\
\text { Excerto } \\
\text { e dia da } \\
\text { reflexão }\end{array}$ & Excertos do Corpus & $\begin{array}{l}\text { Categorias } \\
\text { analisadas } \\
\text { (papéis de } \\
\text { professora) }\end{array}$ \\
\hline $2 \# 14.05$ & $\begin{array}{l}\text { aterrorizar um pouco. }[\ldots] \text { botar alguém pra fora }[\ldots] \text { Eu } \\
\text { pensei }[\ldots] \text { em chegar um dia sem avisar }[e] \text { dar uma prova. }\end{array}$ & $\begin{array}{l}\text { Categoria 1: } \\
\text { Papel de } \\
\text { professora } \\
\text { autoritária e } \\
\text { disciplinadora }\end{array}$ \\
\hline $4 \# 18.06$ & $\begin{array}{l}\text { Eu acho extremamente agressivo, violento se posicionar assim } \\
\text { [...] eu não me sinto à vontade, absolutamente, em fazer o que } \\
\text { eu fiz hoje [...] O professor não deveria ser obrigado a impor a } \\
\text { sua presença, assim, por meio do berro, do grito. }\end{array}$ & $\begin{array}{l}\text { Problematização } \\
\text { dessas ações, } \\
\text { desse papel. }\end{array}$ \\
\hline $5 \# 18.06$ & $\begin{array}{l}\text { Eles mesmos reconhecem isso e parece que a ideia seria mesmo } \\
\text { tirar da sala. A ideia dos próprios colegas [...] se a professora } \\
\text { tirasse da sala seria melhor. }\end{array}$ & \multirow{5}{*}{$\begin{array}{l}\text { Categoria 2: } \\
\text { Papel de } \\
\text { professora } \\
\text { conciliadora. } \\
\text { Dá voz ao } \\
\text { aluno e a si } \\
\text { mesma. }\end{array}$} \\
\hline $10 \# 17.09$ & $\begin{array}{l}\text { Tirar pra fora e conversar [individualmente], eu vou ver se eu } \\
\text { faço isso mais seguido agora [....] e tirar nota, descontar. E isso é } \\
\text { uma estratégia que eles concordam. Me parece justo. }\end{array}$ & \\
\hline $6 \# 20.08$ & $\begin{array}{l}\text { Eu sinto essa necessidade [...] de justificar. Eu tô fazendo assim } \\
\text { porque vocês têm a opção de se movimentar com liberdade na } \\
\text { sala de aula. [...] Eu tenho que desenvolver uma maneira de me } \\
\text { impor dentro daquilo que eu sou. }\end{array}$ & \\
\hline $23 \# 22.10$ & $\begin{array}{l}\text { Isso é uma mensagem que transita naquele contexto ali, que } \\
\text { pessoas diferentes podem trabalhar junto, como elas. }\end{array}$ & \\
\hline $28 \# 19.11$ & $\begin{array}{l}\text { Eu estava com a consciência tranquila [...] eu já tinha tentado } \\
\text { tudo que era possível em termos de civilidade pra lidar com } \\
\text { eles: conversa, dinâmica de grupos, tirar pra fora pra conversar. }\end{array}$ & \\
\hline
\end{tabular}




\begin{tabular}{|c|c|c|}
\hline $20 \# 17.09$ & $\begin{array}{l}\text { A cartilha, todo esse projeto em torno do mercado, da compra } \\
\text { e venda, a gente vai fechar. Vai fechar quando a gente acha que } \\
\text { tem que fechar. E isso é uma vitória. Agora, fecha-se o ciclo [...] } \\
\text { Eu fiz até o ponto que eu achei que tinha que ser feito. }\end{array}$ & \multirow{3}{*}{$\begin{array}{c}\text { Categoria 3: } \\
\text { Papel de } \\
\text { professora } \\
\text { engajada, } \\
\text { política e } \\
\text { pedagogicamente, } \\
\text { com o contexto. }\end{array}$} \\
\hline $21 \# 22.10$ & $\begin{array}{l}\text { Eles se sentem à vontade simplesmente pelo fato de tu sair } \\
\text { daquele ambiente da sala de aula viciado. Tu consegue fazer } \\
\text { com que eles relaxem. }\end{array}$ & \\
\hline $24 \# 05.11$ & $\begin{array}{l}\text { Como o professor tem que estar bem informado pra poder se } \\
\text { movimentar nessa avalanche de informações que eles trazem } \\
{[\ldots] \text { no sentido de reforçar, despertar coisas que eles não }} \\
\text { pensaram ou mesmo desconstruir ideias que não se sustentam. }\end{array}$ & \\
\hline $25 \# 05.11$ & $\begin{array}{l}{[\ldots] \text { mesmo tu tendo consciência das oportunidades e do que }} \\
\text { tu tem que fazer, ainda pode dar tudo tão errado. Eu acho que } \\
\text { a gente devia ser mais preparado também pra saber lidar } \\
\text { quando as coisas dão errado. }\end{array}$ & \multirow[t]{2}{*}{$\begin{array}{l}\text { Problematização } \\
\text { dessas açōes, } \\
\text { desse papel. }\end{array}$} \\
\hline $33 \# 17.12$ & $\begin{array}{l}\text { [...] em cada nova circunstância, eu sou chamada a me posicionar } \\
\text { e esse posicionamento eu pretendo que seja crítico, que seja } \\
\text { consciente, engajado, talvez, não seja neutro. Mas isso não é } \\
\text { uma [...] decisão pessoal, é um exercício. }\end{array}$ & \\
\hline
\end{tabular}

Ao final do trabalho na escola EPF, Cecília reconhece que seu papel como professora também tem um caráter político, visto que assume a responsabilidade de desconstruir ideias e posicionamentos naturalizados, no discurso, como verdade defendidos / trazidos pelos alunos: papel de professora engajada, política e pedagogicamente, com o contexto (Categoria 3, QUADRO 4.1). Vale lembrar que a experiência pedagógica na EPF possibilitou a Cecília constatar sua capacidade de atuar como professora no contexto da escola pública, mas, ao mesmo tempo, a certeza de que esta será sua última opção profissional, tendo em vista sua não-identificação com as políticas pedagógicas praticadas naquele espaço educacional.

\section{Considerações finais}

Cecília problematiza seu papel como professora no contexto de sala de aula, uma vez que precisa administrar as dificuldades disciplinares vivenciadas

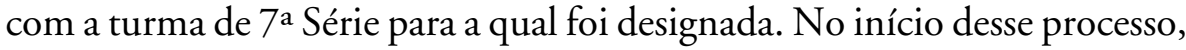
movimenta-se com insegurança no contexto de sala de aula, assumindo e 
reproduzindo papéis que observou em sua vivência escolar como aluna (TSUI, 2007, p. 664). Todavia, não se identifica com eles e vai em busca de novos papéis. Estes se constituem na negociação, com os alunos, de regras de conduta para ambos, que permitissem a ela desenvolver sua prática pedagógica.

Embora Cecília tenha iniciado seu estágio tendo a certeza de que não desejava ser professora, a docência na escola contribuiu para que repensasse essa crença, chegando ao final do processo reflexivo com a certeza de que deseja lecionar. Entretanto, não consegue se identificar com o contexto da escola pública. Acredita que, como professora, deve assumir uma postura crítica e engajada, e esses valores entram em conflito com aqueles perpetuados pelas relações sociais estabelecidas na escola pública. Dessa forma, durante seu processo de socialização como professora pré-serviço, recusa a escola pública como o locus para a realização da sua prática profissional (COLDRON; SMITH, 1999, p. 715).

Isso ocorre principalmente porque, no papel de professora pré-serviço na escola, Cecília percebe a importância de desconstruir as relaçôes de poder que desempoderam o estagiário, embora seu trabalho seja absorvido pela escola. Assume, frente à escola, a responsabilidade por suas decisões e por sua postura pedagógica, mesmo que a instituição, por vezes, não a reconheça como professora de fato. Assim, suas tentativas de alinhamento aos papéis tradicionalmente assumidos pelos professores na escola pública, ao invés de fortalecerem sua identidade como professora, a impediam de compreender $o$ que estava fazendo. Em outras palavras, a afastavam das crenças que estava construindo acerca do que é ser professora (TSUI, 2007, p. 677).

As experiências vivenciadas por Cecília explicitam a necessidade de desenvolvimento de um trabalho colaborativo e continuado entre universidade e escola que permita discutir e reconfigurar o papel do(a) estagiário(a) de inglês. Como há algum tempo argumentam Celani (2003b p. 28) e Magalhães (1996, p. 13), esse projeto colaborativo não pressupõe que todas as partes (estagiários, professores em serviço, orientadores educacionais, supervisores de estágio, pesquisadores) tenham "a mesma compreensão ou o mesmo poder de decisão, mas as mesmas chances de colocar problemas a serem discutidos, refletir, negociar", permitindo que esses processos reflexivos problematizem e reorganizem as práticas sociais vivenciadas no contexto escolar. 


\section{Referências}

ALONSO, T.; FOGAÇA, F. C. Crenças sobre o ensino de inglês na prática de ensino. In: GIMENEZ, T. (Org.). Tecendo as manhãs: pesquisa participativa e formação de professores de inglês. Londrina: UEL, 2007. p. 23-40.

BERGER, P.; LUCKMANN, T. A construção social da realidade. Petrópolis, RJ: Vozes, 1985.

BRUN, M. (Re)construção identitária no contexto de aprendizagem de línguas estrangeiras. In: MOTA, K.; SCHEYERL, D. (Org.). Recortes interculturais na sala de aula de linguas estrangeiras. Salvador: Editora da UFBA, 2004. p. 73-104. COLDRON, J.; SMITH, R. Active location in teacher's construction of their professional identity. Journal of Curriculum Studies, v. 31, n. 6, p. 711-726, 1999.

CORACINI, M. J. Identidade e cidadania: a questão da inclusão. In: CORACINI, M. J. A celebração do outro: arquivo, memória e identidade: Línguas (materna e estrangeira), plurilinguísmo e tradução. Campinas, SP: Mercado de Letras, 2007. p. 97-113.

. Língua estrangeira e língua materna: Uma questão de sujeito e identidade. In: CORACINI, M. J. (Org.). Identidade e discurso. Campinas: Editora da Unicamp; Chapecó: Argos Editora da Universidade, 2003. p. 139-159.

A teoria e a prática: A questão da diferença no discurso sobre a da sala de aula. D.E.L.T.A, v. 14, n. 1. 1998. Disponível em: <http:.../scielo.php?script= sci_arttext\& pid=S0102-4501998000100003\&Ing= pt\&nrm=is $>$. Acesso em: 6 mar. 2002.

FAIRCLOUGH, N. Analysing discouse: textual analysis for social research. London / New York: Routledge, 2003.

. Critical language awareness. London: Longman, 1992.

. Language and power. London: Longman, 1989.

FOUCAULT, M. A hermenêntica do sujeito. São Paulo: Martins Fontes, 2004.

FREIRE, P. Cartas a Cristina: reflexões sobre a minha vida e a minha praxis. Org. e notas Ana Maria Araújo Freire. 2 ed. rev. São Paulo: Editora Unesp, 2003a.

O caminho se faz caminhando: conversas sobre educação e mudança social. Petrópolis: Vozes, 2003 b.

Discurso e mudança social. Brasília: UnB, 2001a.

. Pedagogia da autonomia. São Paulo: Paz e Terra, 2001b.

GREGOLIN, M. R. Foucault e Pêcheux na análise do discurso: diálogos \& duelos. São Carlos, SP: Editora Claraluz, 2006. 
HALL, S. A identidade cultural na pós-modernidade. 10. ed. Rio de Janeiro: DP\&A, 2005.

KRASHEN, S. D.; TERREL, T. D. The natural approach: language acquisition in the classroom. Oxford: Pergamon, 1983.

LEONTIEV, A. El desarrollo del psiquismo. Madri: Akal Editor, 1983.

MERTON, R. Sociologia: teoria e estrutura. São Paulo: Editora Mestre Jou, 1968.

MOITA LOPES, L. P. da. Socioconstrucionismo: discurso e identidades sociais. In: MOITA LOPES, L. P. da (Org.). Discursos de identidades: discurso como espaço de construção de gênero, sexualidade, raça, idade e profissão na escola e na família. Campinas, SP: Mercado de Letras, 2003. p. 13-38.

ROLLEMBERG, A. T. V. M. Histórias de vida de duas professoras: narrativas como instrumento de construção da identidade profissional. In: MOITA LOPES, L. P. da (Org.). Discursos de identidades: discurso como espaço de construção de gênero, sexualidade, raça, idade e profissão na escola e na família. Campinas, SP: Mercado de Letras, 2003. p. 249-271.

SOUZA, D. M. Identidade transversal e política de verdades: políticas curriculares e a construção da identidade do professor de línguas estrangeiras. In: CORACINI, M. J. (Org.). Identidade e discurso. Campinas: Editora da Unicamp; Chapecó: Argos Editora da Universidade, 2003. p. 337-350.

TSUI, A. B. M. Complexities of identity formation: a narrative inquiry of an EFL teacher. TESOL Quarterly, v. 41, n. 4, p. 657-680, 2007.

Recebido em abril de 2009. Aprovado em junho de 2009. 